\title{
What characterises upper secondary vocational education and training?
}

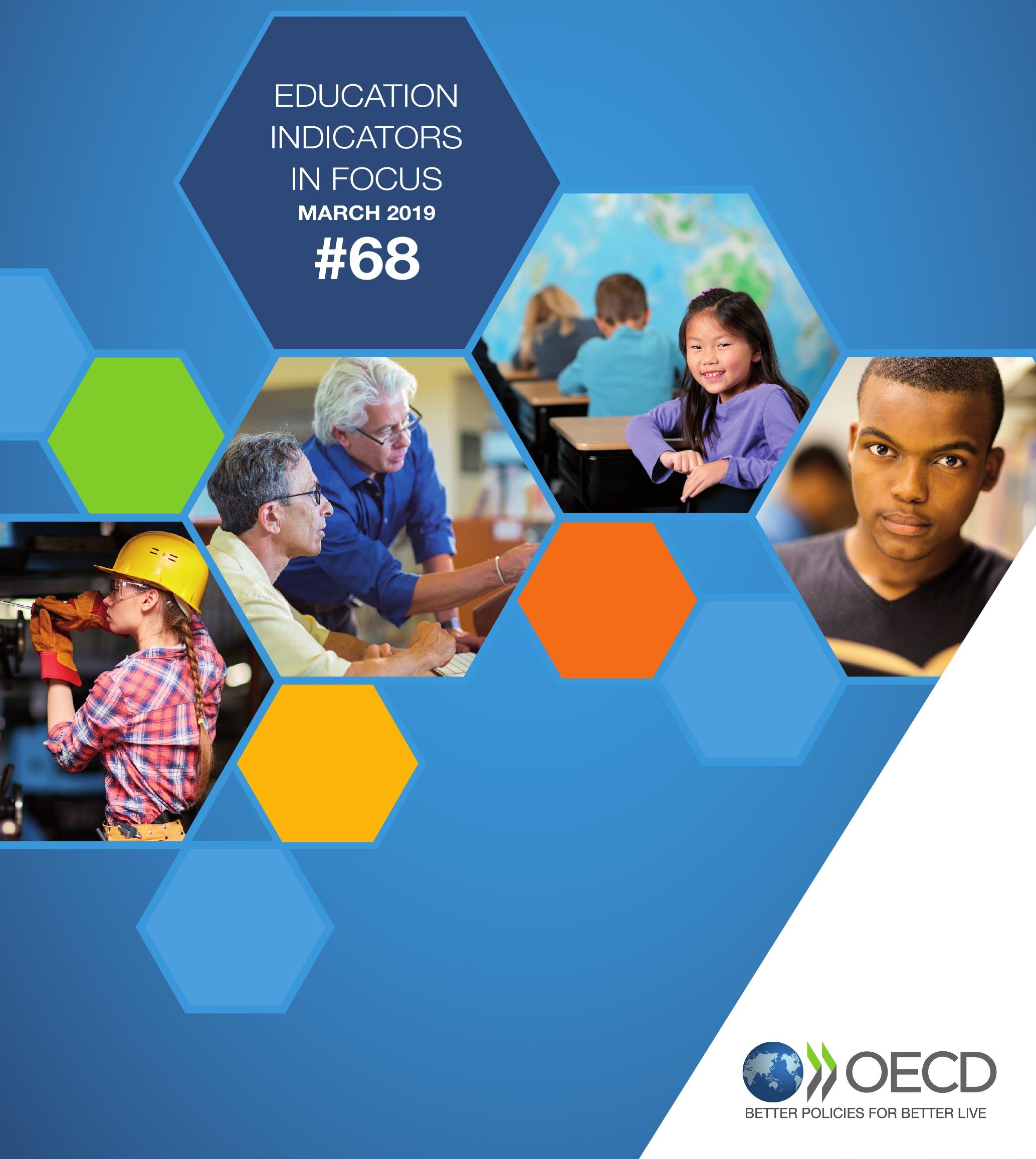


- The diversification programmes offered and opportunities to pursue higherlevel qualifications play a key role in ensuring that vocational education and training are able to meet labour market needs.

- Although programmes combining learning in both the school and work environment provide numerous labour market advantages, only $11 \%$ of students in upper secondary education are enrolled in combined school- and work-based programmes on average across the OECD.

- Students are more likely to disengage from - and even drop out of - the education system in vocational upper secondary programmes than general ones.

- Vocational education and training attracts a very diverse range of students, including youth and adults seeking to improve their technical skills, entry into higher education or those at risk of dropping out of school.

\section{Context}

Upper secondary education builds on students' basic skills and knowledge to prepare them for higher education or the labour market. In many countries, this level of education is not compulsory and it can last from two to five years. Most education systems offer different types of programmes at this level to cater to varying interests and competencies, which will prepare students to contribute fully to society. Developing and strengthening both general and vocational programmes in upper secondary education (see Box 1 for definitions) can make education more inclusive, and strengthen the transition from school to work.

Vocational education and training (VET) is a pathway that attracts a diverse range of students, including those who seek technical skills to enter the labour market, adults who wish to increase their employability by developing their skills further, and students who might seek entry into higher education later on. VET programmes can also be an attractive option to students who struggle academically and are at risk of dropping out of school.

\section{Box 1. Definitions}

- General education programmes are designed to develop learners' general knowledge, skills and competencies, often to prepare them for other general or vocational education programmes at the same or a higher education level. General education does not prepare people for employment in a particular occupation.

- Vocational education and training programmes prepare participants for direct entry into specific occupations without further training. Successful completion of such programmes leads to a vocational or technical qualification that is relevant to the labour market. Vocational programmes are further divided into two categories based on the amount of training provided in school and the workplace: school-based programmes and combined school- and work-based programmes.

- In combined school- and work-based programmes, between $10 \%$ and $75 \%$ of the curriculum is presented in the school environment or through distance education, while the work-based component represents the rest of the curriculum (25-90\%). They include apprenticeship programmes with concurrent schoolbased and work-based training, as well as programmes that alternate periods of attendance at educational institutions with participation in work-based training (sometimes referred to as "sandwich" programmes).

Source: (UNESCO-UIS / OECD / EUROSTAT, 2018 


\section{The state of play of upper secondary vocational education}

On average across OECD countries, 56\% of students in upper secondary education were enrolled in general programmes, while 44\% were enrolled in vocational programmes in 2016. The distribution of upper secondary students enrolled in vocational versus general programmes depends on both the education programmes available and their labour market outcomes. In about one-third of the countries with available data, more upper secondary students were enrolled in vocational programmes than in general programmes, exceeding 70\% in the Czech Republic, Finland and Slovenia. By contrast, in Argentina and Ireland, vocational programmes are not offered at all at this level and in Brazil, Canada and India less than 10\% of upper secondary students are enrolled in vocational programmes (Figure1).

Figure 1 / Share of upper secondary students enrolled in vocational programmes, by type of programme (2016)

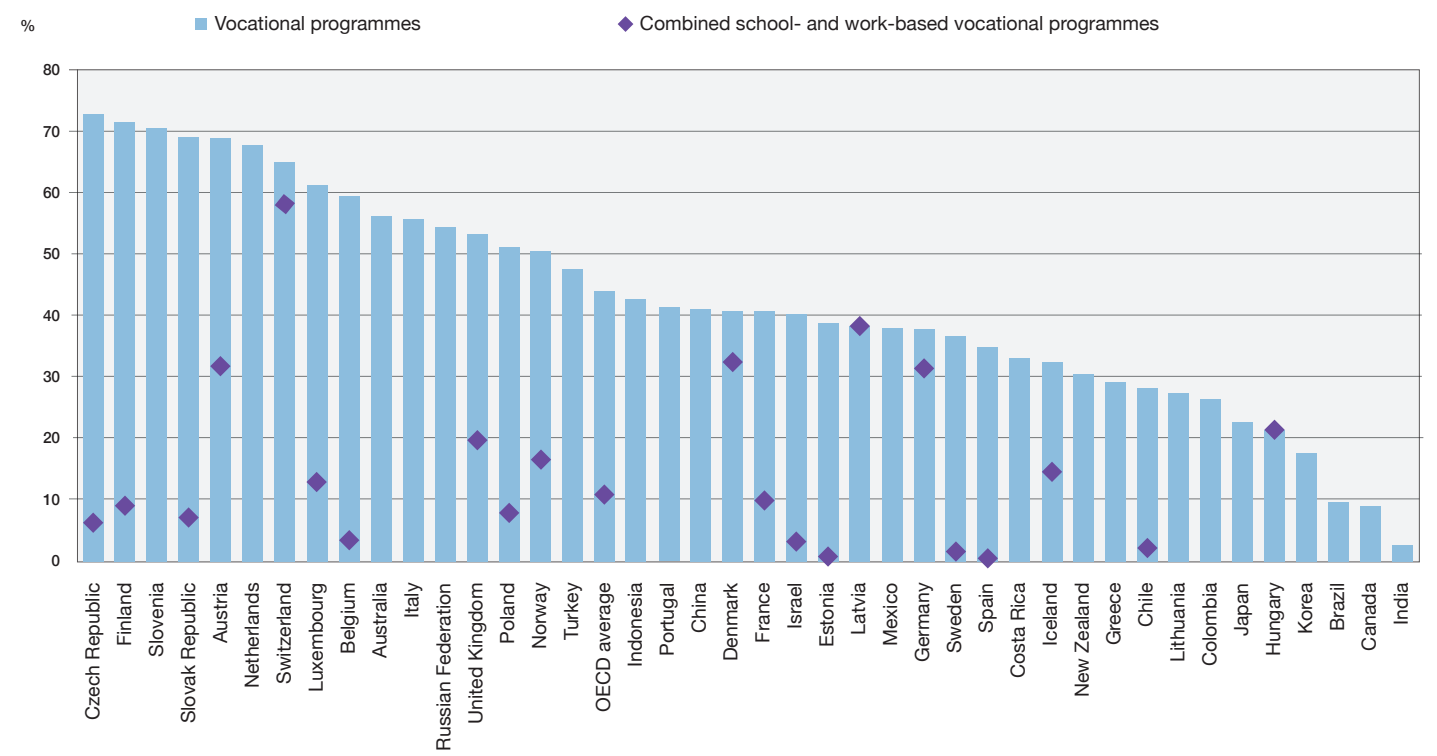

Countries are ranked in descending order of the share of upper secondary students enrolled in vocational programmes. Source: OECD (2018 $\left.{ }_{[2]}\right)$, Education at a Glance 2018: OECD Indicators, https://dx.doi.org/10.1787/eag-2018-en, Table B1.3.

The combination of learning in school and in the work environment through combined school- and workbased programmes provides numerous advantages. Learners get an education that combines practical and theoretical learning. Firms benefit because education can be tailored to workplace needs and students become familiar with firm-specific procedures. Thus, combined school- and work-based programmes reduce skills mismatches and provide hiring opportunities for firms (OECD, 2018 ${ }_{[3]}$ ). It is generally observed that countries maintaining a substantial dual apprenticeship system (on-the-job training combined with formal vocational schooling), such as Austria, Denmark, Germany and Switzerland, also exhibit a much smoother transition from school to work, with low youth unemployment, and a small share of the population neither in employment nor in education and training (Quintini, Martin and Martin, 2007 [4]; Quintini and Manfredi, $\left.2009_{[5]}\right)$.

However, although school- and work-based programmes are offered in 21 OECD countries, only $11 \%$ of students in upper secondary education are enrolled in them. In Hungary and Latvia, all vocational programmes are combined school- and work-based programmes and in Denmark, Germany and Switzerland, more than $80 \%$ of vocational students were enrolled in this type of programme (Figure 1).

The fields of study offered at vocational upper secondary level are progressively diversifying. In 2016, seven out of ten graduates at this level in OECD countries had studied just three broad fields of study: engineering, manufacturing and construction (36\%); business, administration and law (18\%); and services (18\%). Between 2005 and 2016, however, the share of graduates in engineering, manufacturing and construction fell by 3.6 percentage points and by 1.1 percentage points in business, administration and law. In contrast, services and other smaller fields are slowly becoming more popular, like health and welfare, information and communication technologies (ICT), and arts and humanities (Figure 2). 
Figure 2 / Change in the average share of upper secondary vocational graduates by field of study (2005-16)

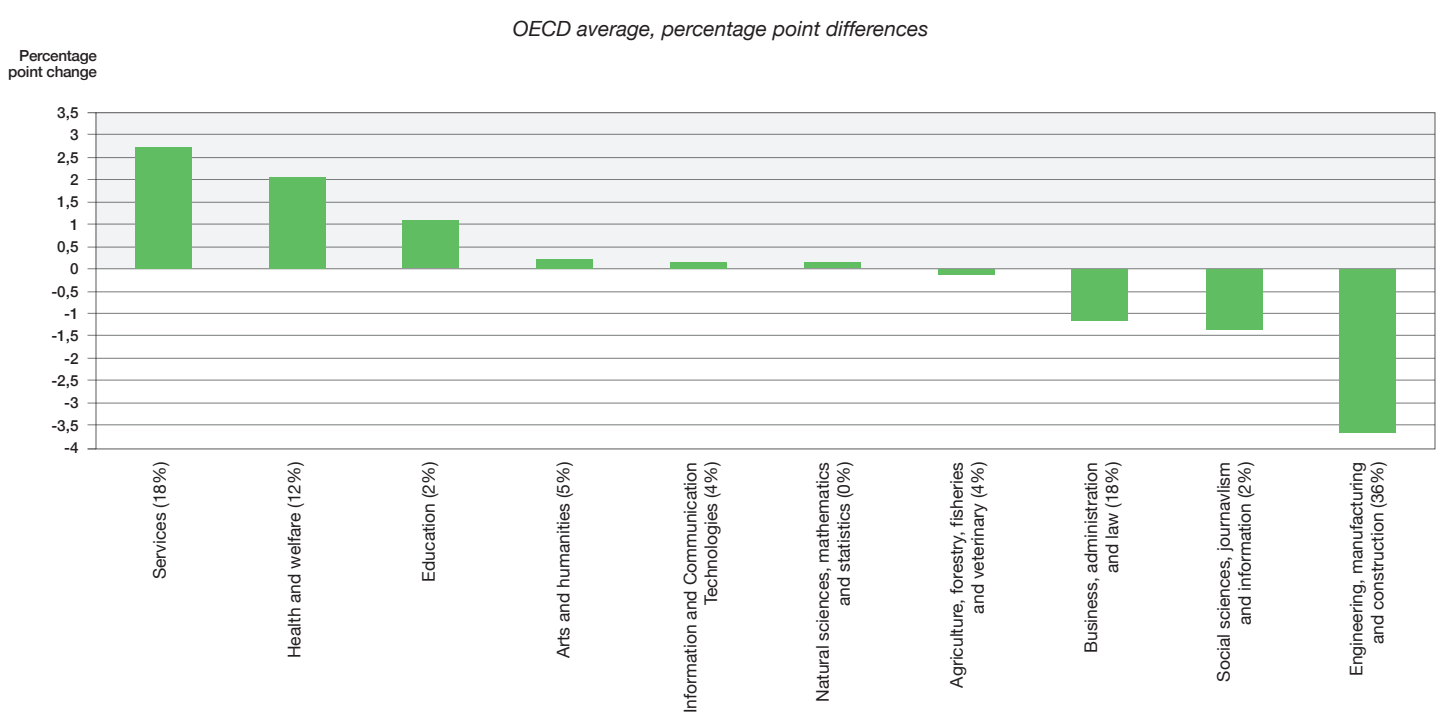

Note: The share of graduates in a specific field of upper secondary vocational programmes in 2016 is indicated in brackets in the legend. This figure includes only countries with available data for the period 2005-16.

Source: OECD Education Database.

Education choices are important for young people, although students may not always have realistic labour market expectations. Some education and training options, and the occupations to which they are a gateway, are often poorly understood (Musset and Mytna Kurekova, 2018 $\left.{ }_{[6]}\right)$. Students' socio-economic background and personal circumstances can also shape their career thinking and have a significant impact on their educational outcomes (OECD, 2018 ${ }_{[2]}$ ), thus making the case for stronger career guidance early on.

\section{Learning outcomes in upper secondary vocational programmes}

The 2016 PISA report Low-Performing Students: Why they Fall Behind and How to Help them Succeed (OECD, $\left.2016_{[7]}\right)$ identified enrolment in vocational tracks as one of the factors most strongly associated with poor student performance among 15-year-olds. The share of low performers among vocational students (41\%) was twice as large as those enrolled in a general track (21\%) on average across OECD countries.

A consequence of low performance is students' disengagement and consequent dropping out from the education system. Young people without an upper secondary qualification tend to face severe difficulties entering - and remaining in - the labour market. This has economic and social consequences for individuals and society alike.

Completion rates at upper secondary level (OECD, 2017 ${ }_{[8]}$ ) indicate to a certain extent the capacity of programmes to engage students throughout their duration. The successful completion of upper secondary programmes can be measured within the theoretical duration of the programme plus two years.

In all countries except Portugal, the completion rate of upper secondary students in a general programme was higher than for those in a vocational programme (Figure 3). On average across countries with available data, $82 \%$ of students in general programmes completed the level within the theoretical duration plus two years, compared to $69 \%$ in vocational programmes. Estonia, Luxembourg and Norway were the countries with the largest gap in completion rates between general and vocational programmes, reaching up to 34 percentage points.

The lower completion rates among students enrolled in vocational programmes may be influenced by students' socio-economic background. In nearly every country with available data, the share of upper secondary students whose parents have not attained upper secondary education is at least twice as high among entrants to vocational programmes as among entrants to general programmes (OECD, 2018 ${ }_{[2]}$ ). 
Figure 3 / Completion rate of upper secondary education by programme orientation, by the theoretical duration plus two years (2015)

Completion rate in full-time students education programmes of at least two years of duration.

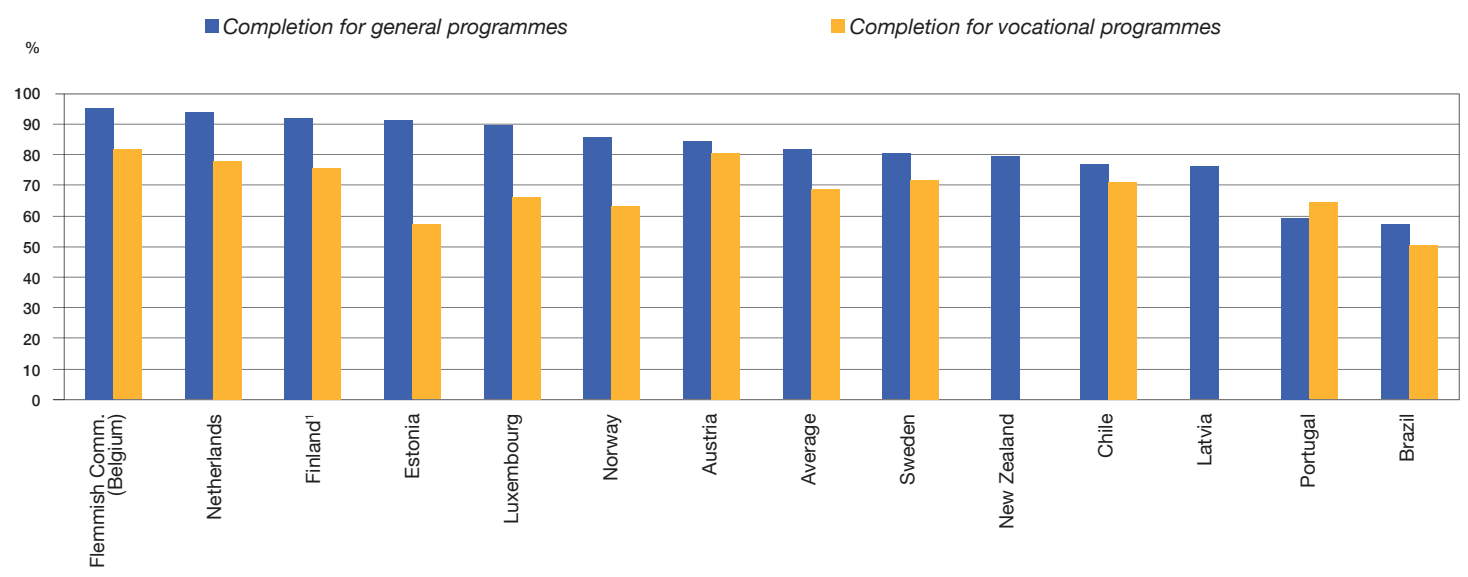

Note: Only countries with true cohort data are shown in this figure. See Methodology section in Indicator A9 (OECD, $\left.2017_{[8]}\right)$.

1. Year of reference 2014.

Countries are ranked in descending order of completion rate in general programmes.

Source: OECD (2017 $\left.{ }_{[8]}\right)$, Education at a Glance 2017: OECD Indicators, https://dx.doi.org/10.1787/eag-2017-en, Table A9.1.

\section{Vocational education and training can play a crucial role in meeting the labour market's needs}

VET can play a crucial role in tackling youth unemployment (Dolado, 2015 ${ }_{[9]}$ ). During economic downturns, such as the 2008 recession, they have been found to be a powerful tool for addressing youth unemployment in countries such as Austria, Germany and Switzerland. These countries' relative success relied on the efficient use of vocational training and apprenticeship institutions. In particular, this related to the so-called "dual system" and the strengthening of "pre-apprenticeship" or "third track" transition systems, targeted at potential school dropouts with limited competencies (Kis, 2016 ${ }_{[10]}$ ). In this latter type of programme, disengaged youths from school are prepared to access the more conventional apprenticeship tracks that do not provide qualifications. An additional effort was made to establish "bridges" from vocational and technical training to formal degrees, opening pathways to higher education.

Students' educational pathways also depend on the opportunity to pursue learning at a later stage (Dunkel and Teichler, 2007 ${ }_{[11]}$ ). Upper secondary vocational tracks may be reinforced by post-secondary options for their graduates. The strongest vocational systems provide a career structure for upper secondary vocational graduates, ensuring they have the opportunity to pursue higher-level vocational and academic qualifications (OECD, 2014 1 ). This can be achieved through the diversification of programmes across initial VET, continuous VET and higher education as well as flexible curricula linking general and vocational education.

Many countries face challenges in ensuring that vocational education and training systems respond effectively to the needs of the labour market. Employers and trade unions must be sufficiently involved in the development of qualifications and curricula, to ensure alignment between fast-changing industry requirements and the qualifications of vocational students (OECD, 2014 ${ }_{[12]}$ ).

\section{The bottom line}

Vocational education and training can play a central role in preparing young people for work and responding to the labour market needs of the economy. While often neglected in the past, an increasing number of countries are recognising that high-quality vocational education and training can make a major contribution to economic competitiveness. In an unpredictable future where jobs will either disappear or transform, vocational education and training, together with work-based learning, can respond to this challenge by offering an excellent opportunity to nurture the skills employers require. 


\section{REFERENCES :}

[9] Dolado, J. (2015), No Country for Young People? Youth Labour Market Problems in Europe, CEPR Press, https://voxeu.org/sites/default/files/file/No Country Young_People_VoxEU.pdf (accessed on 1 March 2019).

[11] Dunkel, T. and U. Teichler (2007), "Through the looking-glass: Diversification and differentiation in Vocational education and training and higher education", in Modernising Vocational Education and Training, European Centre for the Development of Vocational Training (Cedefop), http://www.cedefop.europa.eu/.

[10] Kis, V. (2016), "Work-based learning for youth at risk: Getting employers on board”, OECD Education Working Papers, No. 150, OECD Publishing, Paris, https://dx.doi.org/10.1787/5e122a91-en.

[6] Musset, P. and L. Mytna Kurekova (2018), "Working it out: Career Guidance and Employer Engagement”, OECD Education Working Papers, No. 175, OECD Publishing, Paris, https://dx.doi.org/10.1787/51c9d18d-en.

[2] OECD (2018), Education at a Glance 2018: OECD Indicators, OECD Publishing, Paris, https://dx.doi.org/10.11787/eag-2018-en.

[3] OECD (2018), Seven Questions about Apprenticeships: Answers from International Experience, OECD Reviews of Vocational Education and Training, OECD Publishing, Paris, https://dx.doi.org/10.1787/9789264306486-en.

[8] OECD (2017), Education at a Glance 2017: OECD Indicators, OECD Publishing, Paris, https://dx.doi.org/10.1787/eag-2017-en.

[7] OECD (2016), Low-Performing Students: Why They Fall Behind and How To Help Them Succeed, PISA, OECD Publishing, Paris, https://dx.doi.org/10.1787/9789264250246-en.

[12] OECD (2014), Skills beyond School, Synthesis Report, OECD Reviews of Vocational Education and Training, OECD Publishing, Paris, https://doi.org/10.1787/9789264214682-en (accessed on 28 February 2019).

[5] Quintini, G. and T. Manfredi (2009), "Going separate ways? School-to-work transitions in the United States and Europe", OECD Social, Employment and Migration Working Papers, No. 90, OECD Publishing, Paris, https://dx.doi.org/10.1787/221717700447.

[4] Quintini, G., J. Martin and S. Martin (2007), "The changing nature of the school-to-work transition process in OECD countries", IZA Discussion Papers, No. 2582, Institute for the Study of Labor, http://www.oecd.org/employment/emp/38187773.pdf.

[1] UNESCO-UIS / OECD / EUROSTAT (2018), UOE data collection on formal education. Manual on concepts, definitions and classifications,http://uis.unesco.org/sites/default/files/documents/uoe2016manual 11072016 0.pdf (accessed on 25 March 2019).

\section{CONTACT:}

Corinne Heckmann (Corinne.Heckmann@oecd.org)

Giovanni Maria Semeraro (GiovanniMaria.Semeraro@oecd.org)

Majda Benzidia (Majda.Benzidia@oecd.org)

Photo credit: () Christopher Futcher / iStock; () Marc Romanelli / Gettyimages; ( ) michaeljung / Shutterstock; @ Pressmaster / Shutterstock This work is published under the responsibility of the Secretary-General of the OECD. The opinions expressed and arguments employed herein do not necessarily reflect the official views of OECD member countries.

This document, as well as any data and any map included herein, are without prejudice to the status of or sovereignty over any territory, to the delimitation of international frontiers and boundaries and to the name of any territory, city or area.

The statistical data for Israel are supplied by and are under the responsibility of the relevant Israeli authorities. The use of such data by the OECD is without prejudice to the status of the Golan Heights, East Jerusalem and Israeli settlements in the West Bank under the terms of international law. 